\title{
Monoamine Oxidase A Genotype Predicts Human Serotonin 1A Receptor Availability In Vivo
}

\author{
Brian J. Mickey, ${ }^{1,2}$ Francesca Ducci, ${ }^{3}$ Colin A. Hodgkinson, ${ }^{3}$ Scott A. Langenecker, ${ }^{1,2}$ David Goldman, ${ }^{3}$ and \\ Jon-Kar Zubieta ${ }^{1,2}$ \\ ${ }^{1}$ Molecular and Behavioral Neuroscience Institute and 2Department of Psychiatry, University of Michigan, Ann Arbor, Michigan 48109-0720, and \\ ${ }^{3}$ Laboratory of Neurogenetics, National Institute on Alcohol Abuse and Alcoholism, Rockville, Maryland 20892
}

The serotonergic system, including the serotonin $1 \mathrm{~A}\left(5-\mathrm{HT}_{1 \mathrm{~A}}\right)$ receptor, has been implicated in the pathophysiology of a number of neuropsychiatric disorders. Current data show substantial interindividual variation in the regional concentration of this receptor site, the source of which is unclear. Monoamine oxidase A (MAO-A) is a key regulator of serotonin metabolism, and polymorphic variation in the $\mathrm{X}$-linked MAO-A gene influences its expression. We hypothesized that polymorphism in the MAO-A gene would be associated with sex-specific variation in $5-\mathrm{HT}_{1 \mathrm{~A}}$ receptor expression. We used positron emission tomography and [ $\left.{ }^{11} \mathrm{C}\right] \mathrm{WAY}-100635$ to quantify $5-\mathrm{HT}_{1 \mathrm{~A}}$ receptors in a group of 31 healthy and unmedicated depressed individuals. The same individuals were genotyped for an upstream variable number tandem repeat polymorphism in the promoter of the MAO-A gene. ANOVA of 5- $\mathrm{HT}_{1 \mathrm{~A}}$ receptor availability demonstrated a significant effect of MAO-A genotype in the raphe nuclei, medial and inferior temporal cortex, insula, medial prefrontal cortex, and anterior cingulate $(p<0.05)$. The effect persisted when age, race, body mass index, and diagnosis were included in the model. Genotypes with greater putative MAO-A activity were associated with greater $5-\mathrm{HT}_{1 \mathrm{~A}}$ receptor availability in women, but not in men. Genotype predicted a substantial $42-74 \%$ of the variance in receptor availability in women, depending on the brain region $(p<0.05)$. Depression diagnosis was not associated with MA0-A genotype or 5- $\mathrm{HT}_{1 \mathrm{~A}}$ receptor availability in these regions. These results demonstrate a sexspecific interaction between two key molecules of the human serotonergic system, and suggest a neurobiological basis for sexual dimorphism in serotonin-modulated phenotypes.

Key words: sex difference; polymorphism; positron emission tomography; serotonin; serotonergic 1A receptor; monoamine oxidase; imaging; genetics; human; depression

\section{Introduction}

The serotonergic system regulates a wide range of brain functions. Two relatively well-studied components of this system are the serotonin $1 \mathrm{~A}\left(5-\mathrm{HT}_{1 \mathrm{~A}}\right)$ receptor and monoamine oxidase $\mathrm{A}$ (MAO-A). The 5- $\mathrm{HT}_{1 \mathrm{~A}}$ receptor is a G-protein-coupled receptor that is expressed on the cell bodies and dendrites of neurons in the raphe nuclei, which contain the majority of serotonergic neurons in the brain (Aghajanian et al., 1990; Hensler, 2006). These brainstem serotonergic neurons send projections to widespread forebrain regions, where the targeted postsynaptic neurons also express 5- $\mathrm{HT}_{1 \mathrm{~A}}$ receptors (Aghajanian et al., 1990; Hensler, 2006). After acting at its receptor, serotonin is metabolized by MAO-A. This enzyme is distributed widely throughout the brain, and it is

\footnotetext{
Received May 23, 2008; revised Sept. 11, 2008; accepted Sept. 12, 2008.

This work was supported by National Institute of Mental Health Grants P01 MH42251 and R25 MH6374, National Institute on Alcohol Abuse and Alcoholism Intramural Research Program, and the General Clinical Research Center at the University of Michigan (National Institutes of Health Grant RR00042). We thank Virginia Murphy-Weinberg and the technologists of the PET Center at the University of Michigan for their assistance in the performance of the studies.

Correspondence should be addressed to Jon-Kar Zubieta, Molecular and Behavioral Neuroscience Institute, 205 Zina Pitcher Place, Ann Arbor, MI 48109-0720. E-mail: zubieta@umich.edu.

D0I:10.1523/JNEUROSCI.2391-08.2008

Copyright $\odot 2008$ Society for Neuroscience $\quad$ 0270-6474/08/2811354-06\$15.00/0
}

thought to provide the major pathway for serotonin metabolism (Saura et al., 1996; Shih et al., 1999).

Positron emission tomography (PET) studies of $5-\mathrm{HT}_{1 \mathrm{~A}}$ receptors commonly find significant interindividual variability in binding potential. Some of this variation has been linked to sex (Cidis Meltzer et al., 2001; Parsey et al., 2002), depression diagnosis (Drevets et al., 1999; Sargent et al., 2000; Parsey et al., 2006b), and antidepressant treatment response (Parsey et al., 2006a; Moses-Kolko et al., 2007). Other studies have investigated whether variation in $5-\mathrm{HT}_{1 \mathrm{~A}}$ receptor expression is genetically mediated. A variable number tandem repeat (VNTR) polymorphism in the promoter of the serotonin transporter gene (SLC6A4, s allele) has been associated with lower 5- $\mathrm{HT}_{1 \mathrm{~A}}$ receptor availability in healthy subjects (David et al., 2005). An association with the $-1018(\mathrm{C} \rightarrow \mathrm{G})$ single-nucleotide polymorphism in the $5-\mathrm{HT}_{1 \mathrm{~A}}$ receptor gene was demonstrated in one study (Parsey et al., 2006b), but this was not independently replicated (David et al., 2005). The discovery of further genetic and environmental factors that contribute to variation in $5-\mathrm{HT}_{1 \mathrm{~A}}$ receptor availability is crucial for understanding serotonergic function in normal and diseased states, and for advancing individualized diagnosis and treatment of a number of conditions modulated by this neurotransmitter system.

One potential contributor to variation in $5-\mathrm{HT}_{1 \mathrm{~A}}$ receptor 
Table 1. Demographic and genotype characteristics of the study sample

\begin{tabular}{lll}
\hline & Healthy & Depressed \\
\hline Number of subjects & 17 & 14 \\
Sex (\% female) & 47 & 64 \\
Age (mean \pm SD) & $34 \pm 12$ & $38 \pm 11$ \\
Race (\% Caucasian) & 53 & 64 \\
Body mass index (mean \pm SD) & $26 \pm 4$ & $28 \pm 4$ \\
MA0-A genotype (number of subjects per geno- & & \\
$\quad$ type group) & & \\
L & 5 & 2 \\
H & 4 & 2 \\
L/L & 3 & 2 \\
L/H & 3 & 5 \\
H/H & 2 & \\
\hline
\end{tabular}

L, Low; H, high.

availability is the MAO-A gene. MAO-A knock-out mouse models show increased extracellular serotonin levels and decreased $5-\mathrm{HT}_{1 \mathrm{~A}}$ receptor sensitivity and concentrations (Evrard et al., 2002; Owesson et al., 2002; Lanoir et al., 2006). The reduced expression of $5-\mathrm{HT}_{1 \mathrm{~A}}$ receptors has been explained as compensatory downregulation resulting from excess extracellular serotonin levels in animals that lack functional MAO-A enzyme (Evrard et al., 2002; Owesson et al., 2002; Lanoir et al., 2006). The human MAO-A gene has a putatively functional VNTR polymorphism in its promoter region (Sabol et al., 1998). The 3.5- and 4-repeat alleles are associated with higher MAO-A expression than other alleles in vitro (Sabol et al., 1998; Deckert et al., 1999). Because the gene is X-linked, males are hemizygous at this locus. Females are homozygous or heterozygous and alleles are subject to $\mathrm{X}$ inactivation. Functional polymorphism at the MAO-A locus is thus expected to manifest in a sex-specific manner.

We hypothesized that low-activity MAO-A genotypes would be associated with lower $5-\mathrm{HT}_{1 \mathrm{~A}}$ receptor concentrations in humans, in a manner consistent with findings in animal models, and furthermore that the effects of genotype would differ between men and women. To test this hypothesis, we used PET to quantify $5-\mathrm{HT}_{1 \mathrm{~A}}$ receptors in a group of healthy and depressed individuals, and genotyped the same individuals for the MAO-A promoter polymorphism.

\section{Materials and Methods}

Subjects. Seventeen healthy subjects and 14 unmedicated, treatmentseeking, depressed volunteers were recruited by advertisement for a study of major depression. All subjects were free of psychotropic medications. Ten of the depressed subjects had never taken antidepressant medication and the other four had been off medication for 6-60 months. Demographic information is given in Table 1. Eighteen subjects were Caucasian, six were African-American, and seven had another self-described race (Asian, Pacific Islander, Native American, or mixed). Depressed subjects were diagnosed with moderate-to-severe major depressive disorder (17 item Hamilton Depression Rating Scale mean 18.9, SD 2.6), and healthy controls were determined never mentally ill, using the Structured Clinical Interview for DSM-IV. Subjects with other major health problems or substance abuse (including tobacco use) were excluded. Written informed consent was obtained from each volunteer. The study was approved by the Institutional Review Board and the Radiation Drug Research Committee at the University of Michigan.

Imaging. PET procedures were similar to those described previously (Zubieta et al., 2002). PET images were acquired with a Siemens/CTI $\mathrm{HR}+$ scanner in three-dimensional mode with septa retracted. Volunteers were positioned in the scanner gantry, an antecubital intravenous line was placed, and a light forehead restraint was applied to reduce head movement. [carbonyl- ${ }^{11} \mathrm{C}$ ]WAY-100635, a specific 5-HT $1 \mathrm{~A}$ receptor antagonist, was synthesized at high specific activity (Zhuang et al., 1994;
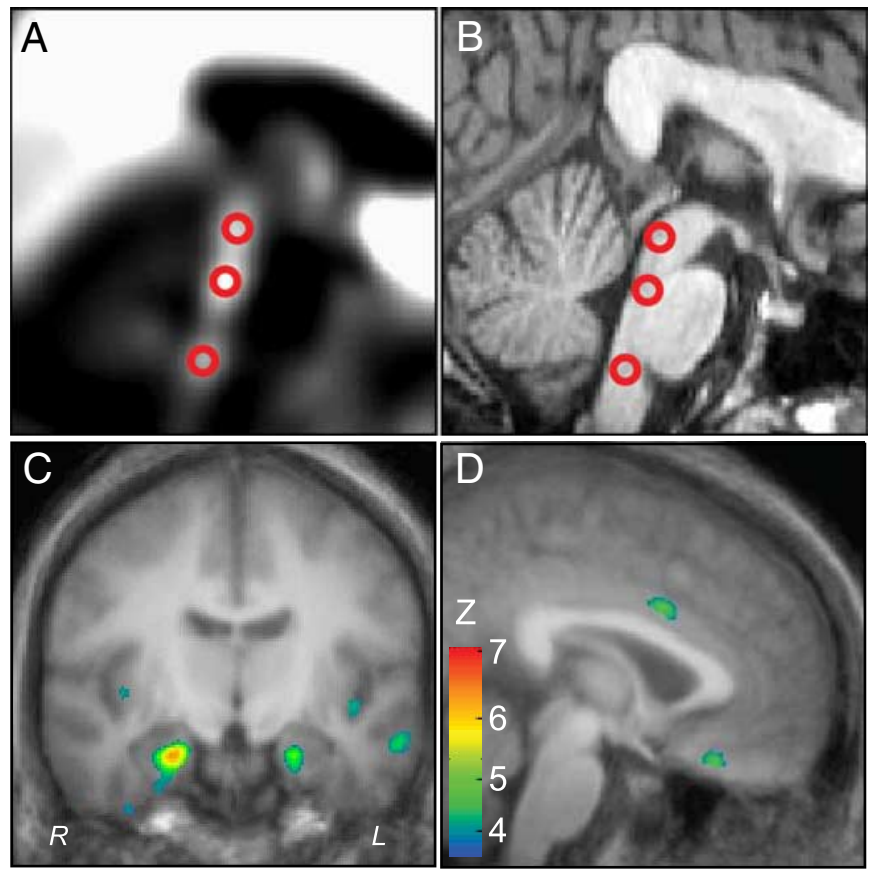

Figure 1. Regional variation of $5-\mathrm{HT}_{1 \mathrm{~A}}$ receptor binding potential with MAO-A genotype. $\boldsymbol{A}$, Mid-sagittal PET image of the brainstem, averaged across subjects, showing three $10 \mathrm{~mm}$ diameter spherical R0Is in the midbrain, rostral pons, and rostral medulla. $\boldsymbol{B}$, T1-weighted MRI coregistered to $\boldsymbol{A}$. $\boldsymbol{C}$, Coronal image at $\boldsymbol{y}=-10 \mathrm{~mm}$ showing several forebrain regions significant by statistical parametric mapping. Colors represent $Z$ scores (threshold, $p=0.001$ ). $D$, Sagittal image at $\mathrm{x}=2 \mathrm{~mm}$ showing significant variation of binding potential in left dorsal anterior cingulate and ventromedial prefrontal cortex. Colors represent $Z$ scores.

Hwang et al., 1999). The tracer was administered as a bolus followed by continuous infusion to more rapidly achieve steady-state conditions. Eighteen scans of increasing duration (0.5-10 $\mathrm{min})$ were acquired over a period of $90 \mathrm{~min}$. Raw PET images were coregistered and smoothed with a Gaussian filter (4 mm full-width at half-maximum). Smoothed images were transformed voxel-by-voxel into parametric maps of tracer transport $\left(\mathrm{K}_{1}\right.$ ratio) and specific binding [distribution volume ratio (DVR)] using a modified Logan graphical analysis, with bilateral cerebellar hemispheres (excluding the vermis) as the reference region (Logan et al., 1996). Binding potential [(BP) i.e., receptor availability] was then defined as DVR-1, or $k_{2} B_{\max } / K_{\mathrm{d}}$, where $B_{\max }$ is the total receptor concentration, $K_{\mathrm{d}}$ is the dissociation constant, and $k_{2}$ is the extracellular concentration of tracer (assumed to be a small, constant value). Two additional individuals showed anomalously low whole-brain binding potential (2.4-3.0 SDs below the mean) and visible binding in the cerebellar hemispheres, and were therefore excluded. Magnetic resonance imaging (MRI) scans were obtained on a 3-T General Electric Signa scanner using axial spoiled gradient-recalled acquisition. PET images were coregistered with MRI images to allow anatomical localization of PET data. Coregistration was accomplished for each subject by alignment of $K_{1}$ images with MRI images using rigid-body affine transformation and a mutual information algorithm (Meyer et al., 1997). MRI data were subsequently transformed into standardized coordinates (International Consortium for Brain Mapping; Montreal Neurological Institute) by linear and nonlinear warping, and the resulting transformation matrix was applied to parametric PET images. The accuracy of coregistration and nonlinear warping was verified for each subject by visual inspection of PET and MRI images.

Genetics. Genomic DNA was purified from blood using standard methods. The MAOA promoter region that contains the upstream VNTR polymorphism (Sabol et al., 1998) was amplified from $10 \mathrm{ng}$ genomic DNA using the primer sequences: Forward 5' CCCAGGCTGCTCCAGAAACATG $3^{\prime}$ and Reverse 5' GTTCGGGACCTGGGCAGTTGTG-3'. Because of the high GC content in the VNTR region, amplification was performed using Invitrogen's PlatinumTaq and PCRX 
Table 2. Influence of MAO-A genotype on $5-\mathrm{HT}_{1 \mathrm{~A}}$ receptor binding potential across brain regions

\begin{tabular}{|c|c|c|c|c|c|c|c|}
\hline Region of analysis & Brain region & Coordinates $x, y, z(\mathrm{~mm})^{a}$ & $\begin{array}{l}\text { ROl or cluster } \\
\text { size }\left(\mathrm{mm}^{3}\right)\end{array}$ & $Z$ score $^{b}$ & Effect of genotype $; p, r^{2}$ & Effect of $\operatorname{sex}^{d} ; p, \Delta$ & $\begin{array}{l}\text { Effect of genotype in } \\
\text { women }^{e} ; p, r^{2}\end{array}$ \\
\hline \multirow[t]{3}{*}{ Brainstem } & Midbrain & $0,-28,-11$ & 515 & & $0.023,0.34$ & $0.38,8$ & $0.002,0.53$ \\
\hline & Pons & $0,-31,-25$ & 515 & & $0.069,0.28$ & $0.044,16$ & $0.112,0.27$ \\
\hline & Medulla & $0,-37,-45$ & 515 & & $0.003,0.44$ & $0.41,7$ & $<0.001,0.47$ \\
\hline \multirow[t]{9}{*}{ Forebrain } & Right MTL & $-30,2,-45$ & 5520 & 7.7 & $0.003,0.45$ & $0.024,18$ & $0.002,0.51$ \\
\hline & Left MTL & $27,0,-42$ & 5620 & 7.0 & $0.001,0.50$ & $0.032,17$ & $0.001,0.55$ \\
\hline & Left FFG* & $41,-23,-30$ & 1750 & 6.1 & $0.008,0.40$ & $0.050,17$ & $0.003,0.42$ \\
\hline & Left ITC & $55,-15,-33$ & 119 & 5.1 & $0.010,0.39$ & $0.21,13$ & $0.013,0.53$ \\
\hline & Left dACC & $2,10,31$ & 246 & 4.9 & $<0.001,0.61$ & $0.065,18$ & $<0.001,0.74$ \\
\hline & Left vmPFC & $2,28,-22$ & 227 & 4.9 & $0.006,0.42$ & $0.088,16$ & $0.012,0.49$ \\
\hline & Left ITG & $58,-9,-18$ & 262 & 4.8 & $<0.001,0.59$ & $0.058,14$ & $<0.001,0.71$ \\
\hline & Left alns & $39,10,-2$ & 187 & 4.7 & $0.009,0.40$ & $0.070,13$ & $<0.001,0.48$ \\
\hline & Left plns & $40,-8,-8$ & 288 & 4.6 & $0.009,0.39$ & $0.20,11$ & $<0.002,0.49$ \\
\hline
\end{tabular}

MTL, Medial/inferior temporal lobe; FFG, fusiform gyrus; ITC, inferior temporal cortex; dACC, dorsal anterior cingulate cortex; vmPFC, ventromedial prefrontal cortex; ITG, inferior temporal gyrus; alns, anterior insular cortex; plns, posterio insular cortex; ${ }^{*}$ cluster drops out when body mass index is included as a covariate.

anternational Consortium for Brain Mapping coordinates.

${ }^{b}$ Z score from SPM analysis, corrected for multiple comparisons.

'One-way analysis of variance ( $\mathrm{df}=4,26)$, uncorrected for multiple comparisons.

${ }^{d}$ Two-tailed, two-sample $t$ test $(\mathrm{df}=29)$, women compared to men, uncorrected for multiple comparisons; $\Delta$, percentage increase of binding potential in women over men.

${ }^{e}$ One-way analysis of variance $(\mathrm{df}=2,14)$, women only, uncorrected for multiple comparisons.

Enhancer System kits (Invitrogen), according to the manufacturer's protocol with $5 \mu \mathrm{M}$ of each primer and $2.5 \mathrm{~mm}$ dNTPs in a total reaction volume of $15 \mu$ l. Amplifications were performed on a Perkin-Elmer 9700 thermocycler (Applied Biosystems) with one cycle at $96^{\circ} \mathrm{C}$ for $10 \mathrm{~min}$ followed by 35 cycles of $94^{\circ} \mathrm{C}$ for $15 \mathrm{~s}, 55^{\circ} \mathrm{C}$ for $15 \mathrm{~s}, 72^{\circ} \mathrm{C}$ for $30 \mathrm{~s}$, and a final 3 min extension at $72^{\circ} \mathrm{C}$. The forward primer was labeled with the fluorescent dye 6-FAM, and amplicons were visualized on an ABI 3730 capillary Sequencer. Allele sizes (3-repeat, 213 bp; 3.5-repeat, 229 bp; 4-repeat, 243 bp; 5-repeat, 373 bp) were determined using Genotyper 4.0/software (Applied Biosystems).

Each subject was classified into one of five groups based on MAO-A genotype. In vitro data suggest that 3.5- and 4-repeat alleles are associated with greater gene expression than other alleles (Sabol et al., 1998; Deckert et al., 1999). Allele frequencies in the sample were $44,0,54$, and $2 \%$ for the 3-, 3.5-, 4-, and 5-repeat alleles, respectively. For statistical analyses, we designated the 3.5- and 4-repeat alleles as high-activity and the 3- and 5-repeat alleles as low-activity. Each male was therefore classified as low or high, and each female as low/low, low/high, or high/high (i.e., each subject fell into one of five groups). Genotype data are shown in Table 1. The 5-repeat allele was found to be low-expressing in one study (Sabol et al., 1998) but not a second study (Deckert et al., 1999); when we instead classified the 5-repeat allele as high-activity, our results were not substantially altered, because this merely resulted in reclassification of one female subject from low/low to low/high.

Analysis. We used region-of-interest (ROI) analysis for brainstem (raphe) regions, because statistical parametric mapping (SPM) tends to be less sensitive for the small nuclei in this structure. We identified three brainstem ROIs in PET images. An average BP image across all subjects was first created (Fig. $1 A, B$ ). Inspection of this average image revealed three distinct peaks on the midsagittal plane in the midbrain (coordinates $x, y, z$ in $\mathrm{mm} 0,-28,-11)$, pons $(0,-31,-25)$, and medulla $(0$, $-37,-45)$. These coordinates were then used to guide the manual placement of three ROIs ( $10 \mathrm{~mm}$-diameter, three-dimensional spheres) on the individual images of each subject, blind to the subject's identity. The primary analysis consisted of one-way ANOVA on each ROI with genotype group (low, high, low/low, low/high, or high/high) as the predictor and $\mathrm{BP}$ values as the dependent variable. Statistics were performed with SPSS 16.0 with a threshold of $p=0.05$ for each ROI.

To identify cortical regions in which binding potential varied by genotype, we used a modified version of Statistical Parametric Mapping (SPM99; Wellcome Department of Cognitive Neurology, University College London, London, UK) and Matlab (MathWorks) software, after previously described methods (Zubieta et al., 2002). We used one-way (ANOVA) with genotype group as the predictor. A statistical $F$ map was generated using the pooled variance across voxels (Worsley et al., 1992), and $p$ values were computed with correction for multiple comparisons using the Euler characteristic (Worsley, 1994) based on the number of voxels in the gray matter and image smoothness (Friston et al., 1991). Data from significant clusters ( $F$ test, $p<0.05$, corrected for multiple comparisons, $>10$ voxels per cluster) were extracted.

Post hoc statistical analysis was performed on extracted mean binding potential values from brainstem ROIs and significant forebrain clusters. Potential confounding variables (diagnosis, Hamilton depression score, age, race, and body mass index) were investigated by adding each as a covariate for forebrain (SPM) and brainstem (SPSS) analyses.

\section{Results}

We first tested the hypothesis that $5-\mathrm{HT}_{1 \mathrm{~A}}$ receptor binding potential is influenced by MAO-A genotype. In the brainstem, ANOVA demonstrated a significant effect of genotype in two of the three ROIs (Fig. 1 $A, B$, Table 2). In the forebrain (SPM analysis) (Fig. $1 C, D$ ), nine forebrain regions were identified in which binding potential was predicted by genotype group $(p<0.05$, corrected) (Table 2). These included the anterior cingulate cortex, ventromedial frontal cortex, medial and inferior temporal neocortex, hippocampus and amygdala (Table 2).

Post hoc analyses showed that the effect of MAO-A genotype differed between women and men. When MAO-A genotype was ignored, $5-\mathrm{HT}_{1 \mathrm{~A}}$ receptor availability was $7-18 \%$ greater in women compared with men across the regions above, and the difference reached statistically significant thresholds (unpaired two-tailed $t$ tests, $p<0.05$ ) in three of those regions (Table 2). Effects of genotype were then explored separately in women and in men. Significant effects of genotype were obtained in women in 11 of 12 regions, with $5-\mathrm{HT}_{1 \mathrm{~A}}$ receptor $\mathrm{BP}$ generally increasing with the number of high-activity MAO-A alleles carried (Table 2, Fig. 2). In women, genotype accounted for $42-74 \%$ of the variance in BP values, depending on the brain region $\left(r^{2}=0.42-\right.$ 0.74 ) (Table 2). None of the regions identified in the voxel-byvoxel analysis showed effects of genotype among men. One of the ROIs, placed in the medulla, showed significant effects of genotype group in males $\left(\mathrm{df}=1,12 ; F=7.0 ; p=0.02, r^{2}=0.37\right)$, but the direction of the effect was opposite that of women (higher BP among those with the low-activity genotype).

The effect of genotype on 5- $\mathrm{HT}_{1 \mathrm{~A}} \mathrm{BP}$ persisted even when controlling for potential confounders. We found no effect of depression diagnosis. When diagnosis or Hamilton depression 

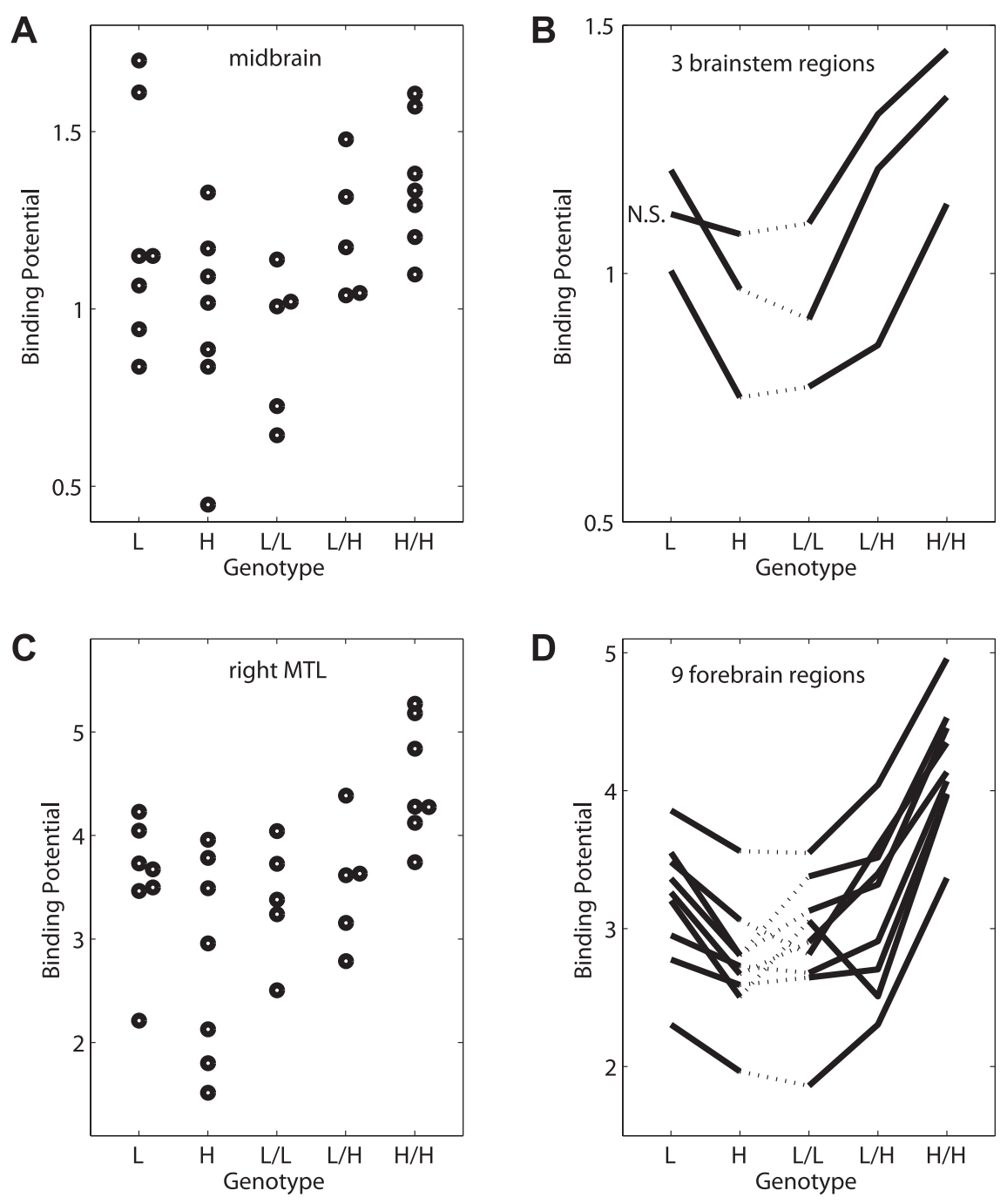

Figure 2. $\quad 5-\mathrm{HT}_{1 \mathrm{~A}}$ receptor binding potential depends on MAO-A genotype. $\boldsymbol{A}$, Binding potential of individual subjects in midbrain ROI versus genotype. L, Low-activity allele; $\mathrm{H}$, high-activity allele. $\boldsymbol{B}$, Mean binding potential in three brainstem ROIs versus genotype. Midbrain and medulla ROIs are significant by ANOVA ( $p<0.05)$; the pons ROl is nonsignificant (N.S.). C, Binding potential of individual subjects in right medial/inferior temporal lobe (MTL) cluster versus genotype. $D$, Mean binding potential in nine forebrain regions versus genotype. All regions are significant by ANOVA ( $p<0.05)$.

score was included in the primary model as a nuisance covariate, the significance of brainstem and forebrain regions was unchanged (data not shown). When depressed patients and healthy controls were compared, the binding potential in each of the 12 identified brain regions did not differ between the two groups (unpaired two-tailed $t$ tests, $\mathrm{df}=29, p>0.2$ ). Furthermore, BP varied similarly with genotype in the depressed and healthy groups (data not shown). A similar lack of effects was obtained when age or race were included in the model (data not shown). When body mass index was included in the model, a large cluster centered in the left fusiform cortex became nonsignificant, but the results for other brainstem and forebrain regions were not substantially changed (Table 2). No significant effects of plasma levels of testosterone (in men), or estradiol or progesterone (in women) on $5-\mathrm{HT}_{1 \mathrm{~A}} \mathrm{BP}$ were observed (data not shown).

\section{Discussion}

This study describes a substantial effect of MAO-A genotype in women on brain regional $5-\mathrm{HT}_{1 \mathrm{~A}}$ receptor $\mathrm{BP}$, predicting $42-$ $74 \%$ of its variance. Higher-activity MAO-A genotypes in women, but not in men, were associated with greater $5-\mathrm{HT}_{1 \mathrm{~A}}$ receptor $\mathrm{BP}$ in numerous brainstem and forebrain regions. When women in the low/low and high/ high MAO-A functional groups were compared, Cohen's effect sizes were 1.8-3.3, depending on the brain region. By comparison, we calculate an effect size of $\sim 0.5-1$ in a study of the VNTR promoter polymorphism in the serotonin transporter gene (David et al., 2005), and an effect size of $\sim 1$ in a study of the $-1018(\mathrm{C} \rightarrow \mathrm{G})$ single-nucleotide polymorphism in the $5-\mathrm{HT}_{1 \mathrm{~A}}$ receptor gene (Parsey et al., 2006b). Thus, the effect sizes we found are larger than those previously reported for genotype effects on $5-\mathrm{HT}_{1 \mathrm{~A}}$ receptor availability.

In contrast to the strong association in women, we found little or no dependence of $5-\mathrm{HT}_{1 \mathrm{~A}}$ receptor availability on genotype among men. The origin of this sex difference is unclear. It is possible that MAO-A genotype does not determine brain levels of MAO-A in men, as suggested by a recent PET study (Fowler et al., 2007). The sex differences we observe mirror those found in a study of monoamine metabolite concentrations in CSF (Jönsson et al., 2000). Among women, the concentration of the major serotonin metabolite, 5-hydroxyindoleacetic acid, was greater in those with a high-activity genotype than in those with low-activity genotype, whereas among men, a nonsignificant trend in the opposite direction was found. Individuals with a high-activity MAO-A genotype would be expected to have greater serotonin turnover, higher metabolite levels, lower synaptic serotonin levels, and compensatory upregulation of $5-\mathrm{HT}_{1 \mathrm{~A}}$ receptors. This model is consistent with studies in MAO-A knock-out mice, in which the complete abolishment of enzyme function was associated with the opposite effects: greater extracellular serotonin levels, reduced $5-\mathrm{HT}_{1 \mathrm{~A}}$ receptor sensitivity, and decreased 5- $\mathrm{HT}_{1 \mathrm{~A}}$ receptor density (Evrard et al., 2002; Owesson et al., 2002; Lanoir et al., 2006). In a recent functional MRI study of healthy participants, interaction effects between sex and MAO-A genotype were described on activation in medial temporal lobe and dorsal anterior cingulate (Meyer-Lindenberg et al., 2006), regions in which we also found a robust sexgenotype interaction on receptor levels. An interaction effect between MAO-A genotype and testosterone level on male antisocial behavior was recently demonstrated (Sjöberg et al., 2008), but we found no such effect on $5-\mathrm{HT}_{1 \mathrm{~A}}$ receptor $\mathrm{BP}$.

Investigators have become increasingly aware of sex differences in the brain, including those involving the serotonergic system (Cahill, 2006; Cosgrove et al., 2007). Women and men have different whole blood serotonin concentrations (Ortiz et al., 1988; Weiss et al., 2005), cerebral serotonin synthesis (Nishizawa et al., 1997), and raphe neuron morphology in infancy (Cordero et al., 2000, 2001). Several studies have demonstrated higher 
$5-\mathrm{HT}_{1 \mathrm{~A}}$ receptor availability in women compared with men (Arango et al., 1995; Cidis Meltzer et al., 2001; Parsey et al., 2002). We found that women with high-activity MAO-A genotypes differ from men and from women with a low-activity genotype, which suggests that women with high-activity MAO-A genotypes may drive some previously reported sex differences in serotonergic mechanisms.

The biological sex differences described above are likely to contribute to sexually dimorphic behaviors associated with serotonergic function such as aggression [for review, see Miczek et al. (2007)] and emotional memory [for review, see Cahill (2006)] , as well as sexually dimorphic psychiatric illnesses like mood disorders (Kessler et al., 1993; Grant et al., 2005), anxiety disorders (Wittchen et al., 1994; Grant et al., 2006), and eating disorders (Kaye et al., 2005).

Although our study included healthy and depressed individuals, a larger sample will be needed to allow us to address several important clinical questions, for example, whether genotype interacts with diagnosis, response to treatment, trait impulsivity, suicidality, or other endophenotypes. We found no significant effect of depression diagnosis on $\mathrm{BP}$ in brain regions that are modulated by MAO-A genotype. Recent studies of the effect of depression on $5-\mathrm{HT}_{1 \mathrm{~A}}$ receptor availability have been discrepant. Although some investigators have described reduced BP in those with major depression (Drevets et al., 1999; Sargent et al., 2000; Bhagwagar et al., 2004; Meltzer et al., 2004; Moses-Kolko et al., 2007), others have found elevated BP and a dependence on antidepressant exposure (Parsey et al., 2006b). Our results do not provide a resolution of this controversy, but suggest that differences among studies could be influenced by genotype and genotype-sex interactions.

In conclusion, our results demonstrate a sex-specific interaction between two key molecules of the human serotonergic system. The sex-dependent influence of MAO-A genotype on $5-\mathrm{HT}_{1 \mathrm{~A}}$ receptor availability suggests a neurobiological basis for sexual dimorphism in serotonin-mediated behaviors and disorders.

\section{References}

Aghajanian GK, Sprouse JS, Sheldon P, Rasmussen K (1990) Electrophysiology of the central serotonin system: receptor subtypes and transducer mechanisms. Ann N Y Acad Sci 600:93-103; discussion 103.

Arango V, Underwood MD, Gubbi AV, Mann JJ (1995) Localized alterations in pre- and postsynaptic serotonin binding sites in the ventrolateral prefrontal cortex of suicide victims. Brain Res 688:121-133.

Bhagwagar Z, Rabiner EA, Sargent PA, Grasby PM, Cowen PJ (2004) Persistent reduction in brain serotonin $1 \mathrm{~A}$ receptor binding in recovered depressed men measured by positron emission tomography with [11C]WAY-100635. Mol Psychiatry 9:386-392.

Cahill L (2006) Why sex matters for neuroscience. Nat Rev Neurosci 7:477-484.

Cidis Meltzer C, Drevets WC, Price JC, Mathis CA, Lopresti B, Greer PJ, Villemagne VL, Holt D, Mason NS, Houck PR, Reynolds CF 3rd, DeKosky ST (2001) Gender-specific aging effects on the serotonin 1A receptor. Brain Res 895:9-17.

Cordero ME, Valenzuela CY, Torres R, Rodriguez A (2000) Sexual dimorphism in number and proportion of neurons in the human median raphe nucleus. Brain Res Dev Brain Res 124:43-52.

Cordero ME, Rodriguez A, Torres R, Valenzuela CY (2001) Human raphe magnus nucleus: a morphometric golgi-cox study with emphasis on sex differences. Brain Res Dev Brain Res 131:85-92.

Cosgrove KP, Mazure CM, Staley JK (2007) Evolving knowledge of sex differences in brain structure, function, and chemistry. Biol Psychiatry 62:847-855.

David SP, Murthy NV, Rabiner EA, Munafó MR, Johnstone EC, Jacob R, Walton RT, Grasby PM (2005) A functional genetic variation of the serotonin (5-HT) transporter affects 5-HT1A receptor binding in humans. J Neurosci 25:2586-2590.

Deckert J, Catalano M, Syagailo YV, Bosi M, Okladnova O, Di Bella D, Nöthen MM, Maffei P, Franke P, Fritze J, Maier W, Propping P, Beckmann H, Bellodi L, Lesch KP (1999) Excess of high activity monoamine oxidase A gene promoter alleles in female patients with panic disorder. Hum Mol Genet 8:621-624.

Drevets WC, Frank E, Price JC, Kupfer DJ, Holt D, Greer PJ, Huang Y, Gautier C, Mathis C (1999) PET imaging of serotonin 1A receptor binding in depression. Biol Psychiatry 46:1375-1387.

Evrard A, Malagié I, Laporte AM, Boni C, Hanoun N, Trillat AC, Seif I, De Maeyer E, Gardier A, Hamon M, Adrien J (2002) Altered regulation of the 5-HT system in the brain of MAO-A knock-out mice. Eur J Neurosci 15:841-851.

Fowler JS, Alia-Klein N, Kriplani A, Logan J, Williams B, Zhu W, Craig IW, Telang F, Goldstein R, Volkow ND, Vaska P, Wang GJ (2007) Evidence that brain MAO A activity does not correspond to MAO A genotype in healthy male subjects. Biol Psychiatry 62:355-358.

Friston KJ, Frith CD, Liddle PF, Frackowiak RS (1991) Comparing functional (PET) images: the assessment of significant change. J Cereb Blood Flow Metab 11:690-699.

Grant BF, Stinson FS, Hasin DS, Dawson DA, Chou SP, Ruan WJ, Huang B (2005) Prevalence, correlates, and comorbidity of bipolar I disorder and axis I and II disorders: results from the National Epidemiologic Survey on Alcohol and Related Conditions. J Clin Psychiatry 66:1205-1215.

Grant BF, Hasin DS, Stinson FS, Dawson DA, Goldstein RB, Smith S, Huang B, Saha TD (2006) The epidemiology of DSM-IV panic disorder and agoraphobia in the United States: results from the National Epidemiologic Survey on Alcohol and Related Conditions. J Clin Psychiatry 67:363-374.

Hensler JG (2006) Serotonergic modulation of the limbic system. Neurosci Biobehav Rev 30:203-214.

Hwang DR, Simpson NR, Montoya J, Man JJ, Laruelle M (1999) An improved one-pot procedure for the preparation of [11C-carbonyl]WAY100635. Nucl Med Biol 26:815-819.

Jönsson EG, Norton N, Gustavsson JP, Oreland L, Owen MJ, Sedvall GC (2000) A promoter polymorphism in the monoamine oxidase A gene and its relationships to monoamine metabolite concentrations in CSF of healthy volunteers. J Psychiatr Res 34:239-244.

Kaye WH, Frank GK, Bailer UF, Henry SE (2005) Neurobiology of anorexia nervosa: clinical implications of alterations of the function of serotonin and other neuronal systems. Int J Eat Disord 37 [Suppl]:S15-S19; discussion $\mathrm{S} 20-\mathrm{S} 21$.

Kessler RC, McGonagle KA, Swartz M, Blazer DG, Nelson CB (1993) Sex and depression in the National Comorbidity Survey. I: Lifetime prevalence, chronicity and recurrence. J Affect Disord 29:85-96.

Lanoir J, Hilaire G, Seif I (2006) Reduced density of functional 5-HT1A receptors in the brain, medulla and spinal cord of monoamine oxidase-A knockout mouse neonates. J Comp Neurol 495:607-623.

Logan J, Fowler JS, Volkow ND, Wang GJ, Ding YS, Alexoff DL (1996) Distribution volume ratios without blood sampling from graphical analysis of PET data. J Cereb Blood Flow Metab 16:834-840.

Meltzer CC, Price JC, Mathis CA, Butters MA, Ziolko SK, Moses-Kolko E, Mazumdar S, Mulsant BH, Houck PR, Lopresti BJ, Weissfeld LA, Reynolds CF (2004) Serotonin 1A receptor binding and treatment response in late-life depression. Neuropsychopharmacology 29:2258-2265.

Meyer CR, Boes JL, Kim B, Bland PH, Zasadny KR, Kison PV, Koral K, Frey KA, Wahl RL (1997) Demonstration of accuracy and clinical versatility of mutual information for automatic multimodality image fusion using affine and thin-plate spline warped geometric deformations. Med Image Anal 1:195-206.

Meyer-Lindenberg A, Buckholtz JW, Kolachana B, R Hariri A, Pezawas L, Blasi G, Wabnitz A, Honea R, Verchinski B, Callicott JH, Egan M, Mattay V, Weinberger DR (2006) Neural mechanisms of genetic risk for impulsivity and violence in humans. Proc Natl Acad Sci U S A 103:6269-6274.

Miczek KA, de Almeida RM, Kravitz EA, Rissman EF, de Boer SF, Raine A (2007) Neurobiology of escalated aggression and violence. J Neurosci 27:11803-11806.

Moses-Kolko EL, Price JC, Thase ME, Meltzer CC, Kupfer DJ, Mathis CA, Bogers WD, Berman SR, Houck PR, Schneider TN, Drevets WC (2007) Measurement of 5-HT1A receptor binding in depressed adults before and 
after antidepressant drug treatment using positron emission tomography and [11C]WAY-100635. Synapse 61:523-530.

Nishizawa S, Benkelfat C, Young SN, Leyton M, Mzengeza S, de Montigny C, Blier P, Diksic M (1997) Differences between males and females in rates of serotonin synthesis in human brain. Proc Natl Acad Sci U S A 94:5308-5313.

Ortiz J, Artigas F, Gelpí E (1988) Serotonergic status in human blood. Life Sci 43:983-990.

Owesson CA, Hopwood SE, Callado LF, Seif I, McLaughlin DP, Stamford JA (2002) Altered presynaptic function in monoaminergic neurons of monoamine oxidase-A knockout mice. Eur J Neurosci 15:1516-1522.

Parsey RV, Oquendo MA, Simpson NR, Ogden RT, Van Heertum R, Arango V, Mann JJ (2002) Effects of sex, age, and aggressive traits in man on brain serotonin 5 -HT1A receptor binding potential measured by PET using [C-11]WAY-100635. Brain Res 954:173-182.

Parsey RV, Olvet DM, Oquendo MA, Huang YY, Ogden RT, Mann JJ (2006a) Higher 5-HT(1A) receptor binding potential during a major depressive episode predicts poor treatment response: preliminary data from a naturalistic study. Neuropsychopharmacology 31:1745-1749.

Parsey RV, Oquendo MA, Ogden RT, Olvet DM, Simpson N, Huang YY, Van Heertum RL, Arango V, Mann JJ (2006b) Altered serotonin 1A binding in major depression: a [carbonyl-C-11]WAY100635 positron emission tomography study. Biol Psychiatry 59:106-113.

Sabol SZ, Hu S, Hamer D (1998) A functional polymorphism in the monoamine oxidase A gene promoter. Hum Genet 103:273-279.

Sargent PA, Kjaer KH, Bench CJ, Rabiner EA, Messa C, Meyer J, Gunn RN, Grasby PM, Cowen PJ (2000) Brain serotonin1A receptor binding measured by positron emission tomography with [11C]WAY-100635: effects of depression and antidepressant treatment. Arch Gen Psychiatry 57:174-180.
Saura J, Bleuel Z, Ulrich J, Mendelowitsch A, Chen K, Shih JC, Malherbe P, Da Prada M, Richards JG (1996) Molecular neuroanatomy of human monoamine oxidases A and B revealed by quantitative enzyme radioautography and in situ hybridization histochemistry. Neuroscience 70:755-774.

Shih JC, Chen K, Ridd MJ (1999) Monoamine oxidase: from genes to behavior. Annu Rev Neurosci 22:197-217.

Sjöberg RL, Ducci F, Barr CS, Newman TK, Dell'osso L, Virkkunen M, Goldman D (2008) A non-additive interaction of a functional MAO-A VNTR and testosterone predicts antisocial behavior. Neuropsychopharmacology 33:425-430.

Weiss LA, Abney M, Cook EH Jr, Ober C (2005) Sex-specific genetic architecture of whole blood serotonin levels. Am J Hum Genet 76:33-41.

Wittchen HU, Zhao S, Kessler RC, Eaton WW (1994) DSM-III-R generalized anxiety disorder in the National Comorbidity Survey. Arch Gen Psychiatry 51:355-364.

Worsley KJ (1994) Local maxima and the expected euler characteristic of excursion sets of x2, F, and t fields. Adv Appl Prob 26:13-42.

Worsley KJ, Evans AC, Marrett S, Neelin P (1992) A three-dimensional statistical analysis for CBF activation studies in human brain. J Cereb Blood Flow Metab 12:900-918.

Zhuang ZP, Kung MP, Kung HF (1994) Synthesis and evaluation of 4-(2'methoxyphenyl)-1-[2'-[N-(2"'-pyridinyl)-p-iodobenzamido] ethyl]piperazine (p-MPPI): a new iodinated 5-HT1A ligand. J Med Chem 37:1406-1407.

Zubieta JK, Smith YR, Bueller JA, Xu Y, Kilbourn MR, Jewett DM, Meyer CR, Koeppe RA, Stohler CS (2002) $\mu$-opioid receptor-mediated antinociceptive responses differ in men and women. J Neurosci 22:51005107. 